\title{
PROBLEM KEDISIPLINAN MAHASISWA PROGRAM STUDI MANAJEMEN PENDIDIKAN ISLAM DALAM KULIAH DARING MENGHADAPI PANDEMIK CORONA VIRUS DESEASE-2019 DI FAKULTAS TARBIYAH INSTITUT AGAMA ISLAM NEGERI MADURA
}

\author{
Halimatus Sa'adah dan Ali Nurhadi \\ Prodi Manajemen Pendidikan Islam Institut Agama Islam Negeri Madura \\ Email: alimatus249@gmail.com danwww.nurhadibk@gmail.com
}

\begin{abstract}
Abstrak
Karakter disiplin sudah seharusnya tercipta dari segala aspek aktivitas yang dilakukan termasuk juga disiplin dalam mengikuti aktivitas perkuliahan yang dilaksanakan secara daring oleh mahasiswa Program Studi Manajamen Pendidikan Islam di IAIN Madura. Penelitian ini termasuk pendekatan kualitatif dengan jenis diskriptif, hasil penelitian menunjukkan bahwa: pertama strategi yang digunakan untuk mendisiplinkan mahasiswa dalam kuliah daring diantaranya memperjelas kontrak prkuliahan atau tujuan perkuliahan, memberikan materi pelajaran dengan metode diskusi, memberikan tugas sebagai bahan evaluasi materi yang disampaikan, dan mengumpulkan tugas dengan menggunakan deadline. Kedua faktor pendukungya supaya disiplin dalam kuliah daring diantaranya alat komunikasi seperti ponsel, laptop, dan aplikasi lainnya sebagai media penyampaian informasi antara mahasiswa dengan dosen, dan ketiga faktor penghambatnya yaitu tidak terfasilitasi dengan jaringan internet dan paket kuota internet yang dimiliki dan tidak ketersediaan alat-alat komunikasi lainnya, dan solusi yang seharusnya disediakan yaitu membeli kuota internet dan menggunakan Wi-fi serta IAIN Madura menyediakan sistem pembelajaran dengan situs web e-learning IAIN Madura.
\end{abstract}

Kata Kunci: Disiplin, Kuliah Daring, Pandemik Covid-19

\begin{abstract}
Discipline character should be created from all aspects of the activities carried out, including the discipline in following lecture activities carried out online by students of the Islamic Education Management Study Program at IAIN Madura. This research includes a qualitative approach with a descriptive type, the results of the study show that: first, the strategies used to discipline students in online lectures include clarifying pre-course contracts or course objectives, providing subject matter with the discussion method, giving assignments as material to evaluate the material presented and collecting tasks using deadlines. The two supporting factors are so that discipline in online lectures includes communication tools such as cellphones, laptops, and other applications as a medium for conveying information between students and lecturers, and the three inhibiting factors are not facilitated by internet networks and internet quota packages that are owned and the absence of tools. Other communications and solutions that should be provided are buying internet quotas and using Wi-fi and IAIN Madura providing a learning system with the IAIN Madura e-learning website.
\end{abstract}

Keywords: Discipline. Online Lectures, Covid-19 Pandemic. 


\section{PENDAHULUAN}

Karakter disiplin merupakan kemampuan seseorang untuk disiplin atas dasar pengetahuan dan diimplementasikan pada tindakan. Hakikatnya pengetahuan tentang disiplin sudah seharusnya dipelajarkan sehingga atas dasar kesadaran dirinya maka dapat dibuktikan dengan perbuatan atau tindakan yang dilakukan sehingga terwujud sikap disiplin.

Karakter adalah kepribadian seseorang dlihat dari aspek etis atau moral yang dilakukan jika segala aktivitas yang dilakukan sesuai dengan moral yang diatur maka itu merupakan karakter dari seseorang begitu pula cara berfikir yang baik dan etis juga menunjukkan bahwasanya itu merupaka karakter dari seseorang. Selain itu pula karakter merupakan tabiat atau kebiasaan dari seseorang jika seseorang sudah terbiasa dengan perbuatan yang baik dan bertingkah sesuai moral maka akan timbul kebiasaan untuk selalu bertindak sesuai dengan moral.

Salah satu bagian dari karakter itu adalah disiplin lantas apa itu disiplin. Disiplin adalah upaya seseorang untuk berbuat dan bertindak sesuai dengan kebijakan yang ditetapkan. Dalam artian lain disiplin adalah bimbingan dan arahan dalam berbuat dan bertindak untuk ditaati sebagai bentuk disiplin. ${ }^{1}$

Disiplin ialah tindakan yang menunjukkan perilaku tertib dan patuh pada berbagai ketentuan dan peraturan. Kedisiplinan dapat dapat dilakukan dan diajarkan kepada anak di sekolah maupun di rumah dengan cara membuat semacam peraturan atau tertib yang wajib di patuhi oleh setiap anak. Apabila anak yang melanggar, harus menerima konsekuensi yang telah disepakati. Oleh karena itu, supaya peraturan dapat berjalan dengan baik, handaknya orang tua maupun pendidik menyolisiasikan terlebih dahulu kepada anak-anak. ${ }^{2}$

Untuk menanamkan sikap disiplin itu tidak mudah melainkan membutuhkan kamampuan dan pengetahuan yang luas sehingga dari hasil pengetahuan tersebut benarbenar dapat mempengaruhi pemikiran seseoramg sehingga dari setiap apa yang dikerjakan selalu berpatokan atau berpedoman pada pengetahuan yang didapatkan.

Sesungguhnya dalam membentuk karakter disiplin itu pertama harus mempengaruhi pada pikiran, karena dalam pikiran dapat merekam segala aktivitas yang dilakukan termasuk juga pengalaman, pengetahuan, dan pembiasaan yang terbentuk dalam lingkungannya. Karena dengan pemikiran itu dapat membentuk kebiasaan dalam membentuk karakter disiplin mahasiswa.

Tidak heran apabila dalam proses perkuliahan yang dilaksanakan secara daring selama situasi pandemik covid-19 saat ini proses perkuliahan dialihkan secara daring artinya proses perkuliahan dilakukan secara jarak jauh dan menggunakan media komunikasi sebagai bentuk penyampaian informasi antara mahasiswa dengan dosen.

Mahasiswa Prodi MPI Fakultas Tarbiyah IAIN Madura untuk dapat membentuk mahasiswa yang berkarakter disiplin maka harus mempengaruhi pemikiran mahasiswa

\footnotetext{
${ }^{1}$ Andy Chandra, "HUBUNGAN PERHATIAN ORANG TUA DAN IKLIM SEKOLAH DENGAN DISIPLIN PADA SISWA “(Jurnal Psychomutiara, Volume 1, No 1, 2017), 01.

${ }^{2}$ Rofiatun, and Mohammad Thoha. "MANAJEMEN PEMBINAAN KEDISIPLINAN SANTRI DALAM MENGIKUTI KEGIATAN KEAGAMAAN DI PONDOK PESANTREN NURUS SHIBYAN AMBAT TLANAKAN PAMEKASAN." re-JIEM (Research Journal of Islamic Education Management) 2, no. 2 (2019): 278-287.
} 
tentang pengetahuan dan pembiasaan mahasiswa dalam bertindak dengan sikap disiplin meskipun proses perkuliahan dialihkan secara daring atau tidak secara langsung.

Salah satu bentuk pengimplemintasiannya di IAIN Maduran Prodi MPI Fakultas Tarbiyah bentuk penanaman pengetahuannya yaitu dengan penjelasan yang berupa tujuan pembelajaran atau perkuliahan kemudian dibiasakan dengan sikap disiplin yang berupa aturan yang ditetapkan serta pemantauan seorang dosen dalam mencapai proses pembelajaran atau perkuliahan selama perkuliahan dilaksanakan secara daring sehingga dengan strategi ini dapat membentuk karakter disiplin mahasiswa Prodi MPI Fakultas Tarbiyah IAIN Madura.

Fokus penelitian ini, bagaimana strategi yang digunakan oleh dosen prodi MPI untuk mendisiplinkan mahasiswa dalam kuliah daring menghadapi pandemik covid-19. Apa saja faktor pendukungnya untuk mendisiplinkan mahasiswa dalam kuliah daring menghadapi pandemik covid-19. Apa saja faktor penghambatnya serta solusi yang digunakan selama proses perkuliahan dilaksanakan secara daring.

Berdasarkan hal tersebut dosen Prodi MPI Fakultas Tarbiyah IAIN Madura mempunyai strategi dalam mendisiplinkan mahasiswa prodi MPI yaitu memperjelas kontrak perkuliahan atau tujuan perkuliahan, memberikan materi pembelajaran, memberikan tugas serta mengumpulkan tugas dengan menggunakan deadline, didukung dengan berbagai alat komunikasi lainnya serta didukung dengan jaringan internet serta kuota internet yang dimiliki. Namun ada beberapa faktor penghambatnya yaitu keterbatasan koneksi internet dan jarimgan serta tidak bisa melihat ketuntasan pembelajaran mahasiswa, untuk dapat meminimalisir penghambat ini maka salah satunya yaitu IAIN Madura dapat menyediakan layanan sistem baru yang terpadu untuk melihat pencapaian pembelajaran mahasiswa.

\section{METODE PENELITIAN}

Pendekatan dalam penelitian ini menggunakan pendekatan kualitatif karena data yang didapatkan dalam penelitian ini tidak berupa angka melainkan kata-kata. Pendekatan kualiatatif itu sendiri adalah menggambarkan realita dibalik fenomena yang terjadi dilapangan secara mendalam, rinci dan tuntas. ${ }^{3}$

Adapun jenis dari penelitian ini menggunakan jenis diskriptif karena penelitian ini mendiskripsikan secara mendalam dari beberapa fenomena yang terjadi dilapangan sehingga memiliki beberapa perbedaan dengan fenomena yang lain. Jenis diskriptif itu sendiri memiliki arti strategi dari seorang peneliti untuk mendapatkan suatu informasi terkait masalah diteliliti lebih rinci dan jelas sehingga mudah dalam mendiskripsikan data.

Metode dalam pengumpulan data yang dilakukan oleh seorang peneliti menggunakan tiga metode yaitu wawancara, observasi dan dokumentasi, wawancara adalah suatu percakapan yang memuat sejumlah informasi tentang kejadian yang ada dilapangan. Sedangkan wawancara yang digunakan oleh peneliti yaitu bebas terpimpin atau gabungan karena peneliti dalam melakukan wawancara selain peneliti berpedoman pada pertanyaan yang dibuat oleh peneliti tapi di sisi lain peneliti juga mempertanyakan

\footnotetext{
${ }^{3}$ Muallifah dan Ali Nurhadi, "PELAKSANAAN HUBUNGAN MASYARAKAT (HUMAS) MODEL SIMETRIS DUA ARAH DISEKOLAH MENENGAH PERTAMA NEGERI 1 PADEMAU PAMEKASAN", re-JIEM (Research Journal of Islamic Education Management), (Vol. 3. No 1. June 2020), 03.
} 
lebih dalam tanpa pedoman wawancara tujuannya untuk mendapatkan data lebih dalam, kemudian metode observasi, metode observasi merupakan serangkaian pengamatan yang dilakukan oleh peneliti untuk melihat keadaan yang sebenarnya terjadi dilapangan dengan melalui aktivitas yang dilakukan oleh sumber data. Sedangkan observasi yang dilakukan yaitu observasi partisipatif karena peneliti berpartsipasi langsung terkait aktivitas yang dilakukan oleh sumber data sehingga peneliti mengetahui secara jelas fakta dari data yang sesungguhnya yang ada dilapangan, kemudian menggunakan dokumentasi, dokumentasi itu sendiri merupakan bukti bahwa sudah melakukan penelitian dengan merujuk pada gambar-gambar dari setiap aktivitas yang dilakukan oleh sumber data yang berupa foto-foto tentang data yang didapatkan di lapangan untuk memperkuat data yang ada di lapangan.

Analisis data adalah proses pengumpulan data yang dilakukan oleh seorang peneliti dengan tujuan untuk mendapatkan informasi dari hasil penelitian yang dilakukan oleh seorang peneliti. Sedangkan analisis data yang dilakukan oleh peneliti yaitu menggunakan kondensasi data karena dengan melakukan kondensasi data peneliti tidak dapat membuang data terkait informasi yang didapatkan dilapangan serta masalah yang diteliti, kemudian menggunakan penyajian data karena peneliti merangkum dan mereviu semua hasil data yang dimiliki, kemudian menggunakan kesimpulan sebagai bentuk akhir dari hasil penelitian.

\section{HASIL DAN PEMBAHASAN}

Berdasarkan fokus penelitian maka terdiri dari tiga rumusan masalah. Maka dari itu secara otomatis juga menghasilkan beberapa temuan penelitian. sebagaimana hasil temuan berikut ini:

\section{Strategi Dosen Prodi MPI Untuk Mendisiplinkan Mahasiswa Dalam Kuliah Daring Menghadapi Pandemik Covid-19 Di Fakultas Tarbiyah IAIN Madura.}

Strategi yang digunakan untuk mendisiplinkan mahasiswa prodi MPI dalam kuliah daring Fakultas Tarbiyah IAIN Madura peneliti menghasilkan temuan penelitian bahwa strategi yang digunakan oleh dosen-dosen MPI dalam mendisiplinkan mahasiswa prodi MPI ketika mengikuti aktivitas perkuliahan yaitu pertama dosen memperjelas kontrak prkuliahan yang disepakati oleh mahasiswa dan dosen serta menentukan waktu kapan dimulai dan kapan berakhir dari setiap aktivitas perkuliahan, kedua melakukan sistem diskusi sebagai peroses penyampaian materi pelajaran dengan berupa file dan diperjelas dengan voicenote atau rekaman dan ketiga memberikan tugas sebagai bahan evaluasi pelajaran mahasiswa dan keempat mengumpulkan tugas dengan google classroom karena dapat terotomatis mahasiswa yang disiplin dalam mengumpulkan tugas dan yang tidak disiplin dalam mengumpulkan tugas.

Jika berbicara tentang strategi tentunya tidak ada batas karena strategi itu adalah sebuah ide atau pemikiran dari setiap orang yang diimplemintasikan dan mempunyai nilai baik sehingga ketika melakukan suatu kegiatan banyak berfariasi tetapi pada hakikatnya adalah satu tujuan.

Begitu juga dalam perkuliahan yang dilaksanakan secara daring banyak variasi atau strategi dalam melaksanakan perkuliahan itu khususnya adalah dalam menanamkan kedisiplinan mahasiswa yang berkaitan dengan kepribadian mahasiswa sehingga dari itu banyak strategi dosen dalam menanamkan kedisiplinan dalam 
perkuliahan yang dilaksanakan secara daring tampa harus menggunakan pada konsep teoritis karena sebagai dosen dalam menerapkan berbagai macam strategi itu tentunya harus disesuaikan dengan keadaan di lingkungan sekitarnya.

Namun terlepas dari itu semua khusus sebagai dosen dalam menerapkan perkuliahan yang dilaksanakan secara daring apalagi menggunakan aplikasi WhatsApp karena aplikasi ini yang sering digunakan oleh mahasiswa prodi MPI selain aplikasinya dapat mendukung pada jaringan, aplikasi ini mudah cara penggunaannya .

Berdasarkan hasil wawancara dengan beberapa sumber baik dari mahasiswa dan dosen bahwasanya strategi utama yang digunakan dosen prodi MPI yaitu pertama kali adanya kontrak perkuliahan, atau memperjelas tujuan pembelajaran supaya mahasiswa disiplin dalam mengikuti perkuliahan yang dilaksanakan secara daring karena dengan adanya kontrak perkuliahan dapat menjadi indikator untuk mahasiswa disiplin dalam mengikuti perkuliahan daring.

Selain itu aplikasi yang digunakan oleh mahasiswa IAIN Madura yaitu lebih sering menggunakan WhatsApp, karena banyak kelebihan yang dimiliki oleh aplikasi ini. Namun jika proses perkuliahan menggunakan media WhatsApp maka diharuskan untuk adanya kontrak perkuliahan supaya mahasiswa lebih mudah mendisiplinkan mahasiswa dalam mengikuti perkuliahan yang dilaksanakan secara daring.

Dalam hal ini sejalan dengan teorinya Sup Riatna Adisu Wingnjo sebagai berikut, Strategi yang harusu di susun apabila perkuliahan dilaksanakan secara daring dengan berbasis aplikasi WhatsApp dapat dijadikan tempat forum diskusi dalam perkuliahan daring, aplikasi WhatsApp dapat digunakan dengan menggunakan laptop, atau android sehingga mudah untuk diakses, adapun strategi yang harus digunakan apabila perkuliahan dilaksanakan secara daring adalah sebagai berikut: 1) siapkann Smartphone atau komputer yang sudah terpasang aplikasi WhatsApp, 2) siapkann materii perkuliahann, bisaa berupaa Power Point Slide Video atau materi yang diketik secara langsung, 3) adanya kontrak perkuliahann atau SOP yang harus disepakati oleh mahasiswa dan dosen, 4) untuk administrasi bagian akademik, dosen dimohon untuk menyimpan materi kuliah dan rekap absensi kehadiran mahasiswa (soft file) dan juga bisa disertakann capture proccess perkuliahan yang dilakukan sebagai bukti bahwa kuliah online yang harus dilaksanakan. ${ }^{4}$

Hasil dari wawancara yang ada di lapangan dapat didukung melalui teori yang ada maka dapat memberikan kesimpulan bahwasanya aplikasi WhatsApp ini layak untuk digunakan sebagai alat bantu proses pembelajaran apabila perkuliahan dilaksanakan secara daring, menurut penulis sendiri aplikasi ini mendukung jika digunakan sebagai media dalam proses perkuliahan yang dilaksanakan secara daring. apalagi mahasiswanya berasal dari kalangan tempat pedalaman yang mungkin kurang terfasilitasi dengan jaringan internet.

Sebab dari itu aplikasi ini bisa dijadikan pendukung karena sifatnya tidak banyak membutuhkan jaringan internet atau tidak lambat (lemot) sehingga perkuliahan dapat berjalan secara efektif. Selain itu untuk dapat mendisiplinkan mahasiswa dalam mengikuti perkuliahan yang dilaksanakan secara daring dengan

\footnotetext{
${ }^{4}$ Supriatna Adisuwingnjo, Panduan Pembelajaran Daring Dalam Rangka Menghadapi Pandemik Covid19 (Malang: Politeknik Negeri, 2020), 40.
} 
menggunakan aplikasi WhatsApp maka harus adanya kontrak perkuliahan yang disepakati oleh mahasiswa dan dosen supaya dapat disiplin dalam mengikuti perkuliahan yang dilaksanakan secara daring antara mahasiswa dengan dosen.

Salah satu strategi yang digunakan dalam mendisiplinkan mahasiswa dalam mengikuti perkuliahan yang dilaksanakan secara daring yaitu harus ada SOP atau kontrak perkuliahan yang disepakati oleh mahasiswa dan dosen yang didalamnya berisi tentang aturan-aturan yang harus disepakati selama dalam proses perkuliahan yang dilaksanakan secara daring.

Prodi MPI IAIN Madura bagi kalangan dosen MPI yang menerapkan perkuliahan secara daring dengan menggunakan aplikasi WhatsApp juga mempunyai aturan-aturan khusus atau kontrak perkuliahan yang berisi tentang aturan selama peroses perkuliahan berlangsung, tujuannya untuk mendisiplinkan mahasiswa dalam mengikuti perkuliahan yang dilaksanakan secara daring. Dalam proses perkuliahan tidak lepas dengan penyampaian materi pembelajaran sebagai bentuk ilmu pengetahuan, maka dari itu tidak menutup kmungkinan supaya dosen-dosen mempunyai strategi tertentu dalam menyampaikan materi pelajaran sehingga membuat mahasiswa disiplin dalam menyimak dan melakukan proses perkuliahan.

Adapun strategi yang digunakan oleh dosen-dosen prodi MPI berdasarkan dengan hasil wawancara bahwasanya di Prodi MPI dalam menyampaikan meteri pelajaran ketika perkuliahan dilaksanakan secara daring menggunakan aplikasi WhatsApp materi yang disampaikan dapat berupa file-file yang dikirim oleh dosen sendiri maupun dari pemateri karena sistem yang digunakan di prodi MPI berbeda yaitu lebih kepada proses pembelajaran yang berpusat pada mahasiswa artinya dosen hanya sebagai penengah apabila ada kesalahan, dan dosen juga menyimak apa yang disampaikan oleh mahasiswa terkait materi pembelajaran dengan berbentuk presentasi namun presentasi ini dimulai apabila dosen dan seluruh mahasiswa telah hadir dalam kelas online dengan indikatornya adalah absensi online mahasiswa.

Materi yang disampaikan dapat berupa file-file yang dikirim mahasiswa sebagai penguat dari penjelasn itu selain dijelaskan dengan melalui voicenote atau rekaman maka juga menggunakan Pawerpoint supaya lebih memperjelas meteri yang disampaikan.

Dalam hal ini senada dengan teorinya Herman Dwi Sujono sebagai berikut: dalam memberikan materi pelajaran ketika kuliah learning atau daring maka harus berbentuk dalam format digital atau dalam bentuk file, adapun materi pembelajaran bisa saja berupa file dokumen (doc, pdf, xls,txt), presentasi (ppt), gambarr (jpg/jpeg, gif, png), video (mpg, mwv), suara (mp3, aui,wav), animasii (swf, gif). ${ }^{5}$

Selain itu sebagai bentuk pengevaluasian sejauh mana mahasiswa bisa memahami materi pelajaran yang disampaikan di kelas maka dosen membuat kuis online atau pertanyaan-pertanyaan menurut hasil wawancara dengan beberapa sumber bahwasanya dosen prodi MPI untuk dapat mengetahui sejauh mana pemahaman mahasiswa terhadap materi yang disampaikan itu membuat kuis, bisa saja membuat pertanyaan-pertanyaan yang mengarah pada materi yang disampaikan, dan jika sistem perkuliahan dilakukan dengan diskusi maka setelah proses

\footnotetext{
${ }^{5}$ Herman Dwi Surjono, Membangun Course Elerning Berbasis Moodle (Yogyakarta, UN Y Press, 2010), 13. 
penyampaian materi pelajaran selesai yaitu dibuka sesi tanya jawab, apabila ada masalah terhadap materi yang disampaikan maka bisa dipertanyakan, indikator mahasiswa bisa memahami dengan benar yang disampaikan itu melalui jawaban mahasiswa yang disampaikan karena bisa diketahui melalui jawabanya.

Dari hasil wawancara di lapangan dapat didukung dengan teori menurut Herman bahwasanya dalam proses perkuliahan yang dilaksanakan secara daring tidak hanya berisi materi pembelajaran statis, akan tetapi diperlukan pula adanya aktivitas seperti pemberian tugas dan kuis, forum diskusi, chatting. Tugas dan kuisi merupakan aktivitass pembelajaran yang sangat populer, karena melalui tugass dan kuis pengajar dapat mengevaluasi hasil pembelajaran, keberadaan forum juga diharapkan dapat memicu, berbagaiiaktivitas peserta didik. ${ }^{6}$

Kesamaan dalam teori ini dengan hasil dilapangan yaitu sama-sama membuat tugas baik berupa kuis, diskusi dan lain-lain sebagai bentuk pengevaluasian peserta didik untuk mengetahui sejauh mana peserta didik dapat memahami materi yang disampaikan dalam proses perkuliahan namun di prodi MPI ini lebih kepada diskusi ketika materi pelajaran diberikan dan mahasiswa dapat menyimak materi pelajaran itu maka kemudian dibuka sesi diskusi sebagai bentuk penyelesaian masalah yang ingin dipertanyakan oleh mahasiswa kepada pemateri. Namun apabila pemateri masih belum juga mampu menjawab dengan tuntas maka sebagai dosen adalah penengah sekaligus penyelesaian masalah, selain itu dosen juga memberikan tugas berupa tugas mingguan sebagai penguatan pemahaman mahasiswa terhadap materi yang disampaikan dalam proses perkuliahan yang berupa artikel, jurnal, dan makalah.

Dapat disimpulkan bahwasanya strategi yang digunakan dalam mendisiplinkan mahasiswa ketika mengikuti perkuliahan yang dilaksanakan secara daring yaitu melipuiti: pertama adanya tujuan atau kontrak perkuliahan yang jelas serta disepakati oleh mahasiswa dan dosen, yang didalamnya berisi tentang ketentuan waktu dalam proses kegiatan perkuliahan selain itu sebagai indikator mahasiswa disiplin dalam mengikuti perkuliahan yang dilaksanakan secara daring apabila mahasiswa prodi MPI melaksanakan aktivitas perkuliahan sesuai waktu yang ditentukan, kedua adanya menyampaian materi dengan sistem diskusi, dan ketiga memberikan pertanyaan dan tugas sebagai bentuk evaluasi pembelajaran, keempat mengumpulkan tugas yang dengan menggunakan deadline supaya mahasiswa disiplin dalam mengumpulkan tugas.

Dari berbagai macam strategi yang digunakan maka dapat didukung dengan teorinya Hengki Wijaya sebagai berikut: a) Kegiatan awal yang terdiri atas fase 5 dan 2 di mana dosen memberikan salam pembuka, berdoa, mengecek kesiapan mahasiswa, apresiasi, menyampaikan motivasi dan tujuan pembelajaran yang harus dicapai mahasiswa dan dosen menyampaikan informasi berkenaan dengan materi perkuliahan sebelum melangkah pada kegiatan inti. Kegiatan ini sebelumnya sudah ada apresiasi melalui media sosial, dan penayangan video pendek. Dosen membuat kelompok dan mahasiswa masuk kedalam kelompok berjumlah 3-5 orang secara merata dan memberikan tugas yang akan didiskusikan dalam kelompok. b) Kegiatan inti yang terdiri atas fase 3, 4, dan 5 dimana mahasiswa mengamati model materi

${ }^{6}$ Ibid., hlm 49 
berbentuk video. Mahasiswa mendiskusikan dalam kelompok. materi dan referensi tersebut bersumber dari media sosial misalnyan Blog, Website, Jurnal Online, YouTube, WhatsApp, Instagram, Facebook dan sejenisnya. Mahasiswa bersama dalam kelompok dan setiap kelompok diberikan lembar kerja elektronik untuk mengerjakan tugas sesuai dengan materi yang dipelajarkan dan dikerjakan secara kelompok. Selanjutnya mahasiswa mengerjakan secara mandiri ide dan gagasan kritis terhadap video yang diamati dan menyusun suatu gagasan baru yang akank disajikan dalam bentuk video dan penjelasan, c) kegiatan penutup terdiri atas fase 6 dimana mahasiswa bersama dosen membuat refleksi atas apa yang telah dipelajari dalam materi perkuliahan ini dan membuat suatu pernyataan refleksi yang dibagikan melalui media sosial. Dosen juga menyampaikan pertemuan selanjutnya apa yang perlu diketahui oleh mahasiswa. Dosen dapat meminta mahasiswa menutup proses pembelajaran dengan doa. Dosen menyampaikan salam kepada mahasiswa.

Dalam teorinya Hengki Wijaya ketika peroses perkuliahan atau pembelajaran dilaksanakan secara daring supaya lebih efektif tidak melibatkan banyak mahasiswa akan tetapi dikelompokkan dengan beberapa orang saja yang terdiri tiga sampai empat orang, berbeda dengan mahasiswa Prodi MPI Fakultas Tarbiyah IAIN Madura artinya ketika melaksanakan perkuliahan secara daring itu dapat mencakup semua mahasiswa dalam kelas yang lumrahnya bisa terdiri dari 38-40 orang.

Persamaannya antara teori yang ada dengan hasil dilapangan yaitu strategi yang digunakan dari sistem pembelajarannya sama dari mulai tahap pertama yaitu memperjelas tujuan perkuliahan maka dalam teorinya Hengki Wijaya juga dibahas, kemudian tahap kedua dari mulai memberikan materi, memberikan tugas, menjelaskan materi dengan video dilapangan juga menerapkan hal seperti itu sehingga antara teori dengan dilapangan banyak memiliki kesamaan.

Apabila teori dengan dilapangan memiliki kesamaan maka dapat memberikan suatu kesimpulan bahwasanya strategi yang harus digunakan supaya mahasiswa disiplin dalam mengikuti proses perkuliahan secara daring maka dosen-dosen khususnya di prodi MPI bisa menggunakan teorinya Hengki Wijaya yang sudah dikemukakan diatas karena teori ini sudah atas dasar dengan hasil dilapangan yaitu diprodi MPI Fakultas Tarbiyah IAIN Madura.

\section{Faktor Pendukung Untuk Mendisiplinkan Mahasiswa Dalam Kuliah Daring Menghadapi Pandemik Covid -19 Di Fakultas Tarbiyah IAIN Madura.}

Faktor pendukung untuk mendisiplinkan mahasiswa dalam kuliah daring menghadapi pandemik covid-19 di Fakultas Tarbiyah IAIN Madura dapat menghasilkan temuan penelitian yang peneliti lakukan adalah sebagai berikut:

Faktor pendukung supaya kuliah secara daring dapat terlaksana maka harus memerlukan alat-alat teknologi seperti Hp, Laptop dan komputer yang didalamnya terdapat aplikasi-aplikasi khusus yang digunakan dalam media pembelajaran seperti aplikasi Google Classroom, WhatsApp dan SMS (Short Messege Sevices).

Untuk dapat mendukung kedisiplinan dalam kuliah daring maka membutuhkan jaringan internet dan paket data dari masing-masing proveder, karena dengan jaringan internet dan paket data yang terlengkapi maka proses perkuliahan secara daring dapat berjalan dengan baik dan berdampak pada kedisiplinan mahasiswa dalam mengikuti aktivitas perkuliahan. 
Faktor pendukung yaitu alat yang digunakan supaya segala kegiatan itu dapat berjalan dengan baik sehingga sangat dibutuhkan dalam suatu kegiatan, begitu juga ketika perkuliahan dilakasanakan secara daring tentunya harus memiliki alat-alat pendukung supaya perkuliahan dapat berjalan dengan baik.

Berdasarkan hasil wawancara dengan para dosen dan para dekan serta mahasiswa prodi MPI IAIN Madura yaitu salah satu faktor pendukungnya berupa ketersediaan alat-alat teknologi sebagai alat yang digunakan dalam proses perkuliahan selain itu yaitu tergantung pada aplikasi yang digunakan sebagai sarana dalam proses perkuliahan bisa saja berupa aplikasi WhatsApp, Google Clasroom, dan lain-lainya yang bisa berkomunikasi antara mahasiswa dengan dosen sebagai sistem pertukaran informasi antara mahasiswa dengan dosen.

Dalam hal ini senada dengan teorinya Nizam dan Aris Junaidi menyatakan bahwasanya alat pendukung yang digunakan dalam kegiatan perkuliahan secara daring yaitu: a) Laptop atau komputerr (PC) dan alat komunikasi lain (Handpone). b) Scanner dengan aplikasi OCR, misalnya Primzo Go, Microsoft OneNote, Google keep yang berfungsi untuk memindai gambarr (imager) dan dijadikan teks sehingga dapat dimanipulasi (reeditable textt formaty), c) aplikasi yang mendukung aksesibilitas. $^{7}$

Dapat disimpulkan bahwasanya alat bantu atau alat pendukung utama yang harus dipersiapkan terlebih dahulu dalam melaksanakan perkuliahan yang dilaksanakan secara daring yaitu dengan mempersiapkan beberapa alat-alat teknologi sebagai alat utama. Namun untuk pengoperasian pelaksanaan perkuliahan yang dilaksanakan secara daring ini di tentukan aplikasi apa yang dapat membantu mengefektifkan proses perkuliahan yang dilaksanakan secara daring.

Dalam beberapa kegitan mata pelajaran bisa menggunakan beberapa aplikasi disesuaikan dengan kebutuhan jaringan internet dari setiap tempat, karena tidak semua tempat terfasilitasi dengan jaringan internet yang baik. Alat bantu yang digunakan berupa HP (Handphone), Laptop, dan alat-alat teknologi lainnya

\section{Faktor Penghambat Dan Solusi Untuk Mendisiplinkan Mahasiswa Dalam Kuliah daring Menghadapi Pandemik Covid-19 Di Fakultas Tarbiyah IAIN Madura.}

Faktor penghambat dan solusi yang digunakan dalam menghadapi hambatan tersebut ketika mendisiplinkan mahasiswa prodi MPI dalam mengikuti aktivitas proses perkuliahan yang dilaksanakan secara daring. Adapun hasil dari temuan penelitian yang peneliti lakukan adalah sebagai berikut:

Dalam mendisiplinkan mahasiswa prodi MPI ketika melaksanakan proses perkuliahan secara daring yaitu pertama dosen tidak bisa mengetahui secara langsung pencapaian ketuntasan belajar siswa dikarenakan tidak bisa berintraksi secara langsung, kedua keterbatasan koneksi jaringan internet dan yang ketiga yaitu keterbatasan paket data, dari semua penghambat tersebut maka akan berdampak terhadap kedisiplinan mahasiswa maksudnya mahasiswa tidak bisa disiplin dalam mengikuti aktivitas perkuliahan secara daring.

\footnotetext{
${ }^{7}$ Nizam Aris Junaidi, Panduan Pembelajaran daring bagi mahasiswa dengan disabilitasi netra 2020, (Jakarta: Direktorat Jendral Pendidikan Tiggi, 2020), 10.
} 
Solusi yang harus diberikan dalam menghadapi hambatan tersebut yaitu pertama perkuliahan tetap dilaksanakan secara daring maka kedepannya kampus IAIN Madura membuat program khusus yang dikumpulkan dalam satu format yang didalmnya berisi aktivitas perkuliahan secara daring dan mudah untuk dipantau oleh unit penjaminan mutu dan LPM kemudian yang kedua tidak ada solusi terbaik selain mencari sinyal atau koneksi jaringan internet yang ketiga yaitu dengan membeli paket data supaya proses perkuliahan tetap berlangsung.

Setiap melakukan sesuatu kegiatan maka pasti ada faktor penghambatnya, akan tetapi tidak semua faktor penghambat dapat dijadikan alasan tidak bisa melaksanakan suatu kegiatan karena segala sesuatu yang menjadi penghambat itu ada solusi yang bisa menangani masalah itu sendiri, sehingga tidak ada pedoman khusus dalam teoriteori ilmiyah dalam solusi karena harus disesuaikan dengan permasalahan yang dihadapi.

Begitu juga dalam proses perkuliahan yang dilaksanakan secara daring maka juga memiliki beberapa hambatan salah satu hambatannya menurut hasil wawancara dengan beberapa sumber yaitu berupa teknologi artinya tidak memiliki alat teknologi yang berupa Hp. Lapto, Komputer sebagai alat yang digunakan dalam melakukan suatu kegiatan perkuliahan yang dilakanakan secara daring salah satu faktor penghambatnya yaitu adanya keterbatasan jaringan internet dan kurangnya ketersediaan paket data.

Dalam hal ini senada dengan teorinya Putu Diah Pebriyanti bahwasanya ada beberapa faktor penghambat ketika melaksanakan perkuliahan yang dilaksanakan secara daring salah satunya yaitu adalah sebagai berikut: a) Tidak semua tempat terfasilitas dengan internet, b) Kurangnya personil dalam hal penguasaan bahasa pemograman computer, c) Kecendrungan mengabaikan aspek akademik atau aspek sosial dan sebaliknya mendorong adanya aspek bisnis/ komersial. ${ }^{8}$

Salah satu faktor penghambat yang sering dialami oleh mahasiswa prodi MPI IAIN Madura yaitu kurang terfasilitasi dengan internet karena tidak semua tempat terfasilitasi dengan jaringan internet, meskipun sudah terfasilitasi dengan jaringan internet. Kendala lainnya yaitu keterbatasan ekonomi untuk membeli paket data karena dalam proses perkuliahan yang dilaksanakan secara daring itu tidak lepas dari dua hal pertama paket data dan kedua jaringan internet kalau keduanya ini masih kurang terfasilitasi dengan baik maka akan berdampak pada ketidak disiplinan mahasiswa dalam mengikuti proses perkuliahan.

Dalam menghadapi hambatan-hambatan yang terjadi ketika melaksanakan proses perkuliahan yang dilaksanaka secara daring yang berakibat pada ketidak disiplinan mahasiswa maka harus ada solusi yang bisa mengatasi hambatanhambatan tersebut sehingga mahasiswa khususnya di prodi MPI IAIN Madura bisa disiplin dalam mengikuti perkuliahan secara daring.

Solusi yang ditawarkan tidak selamanya harus beracuan pada teoritis karena harus disesuaikan dengan konteks masalah yang dihadapi adapun masalah yang dihadapi mahasiswa prodi MPI IAIN Madura menurut beberapa hasil wawancara dilapangan yaitu ketidak tersediaan jaringan internet maka solusi yag harus diberikan yaitu bisa mencari jaringan internet atau sinyal yang mendukung, dan itu

${ }^{8}$ Ibid putu diah pebriyanti 
hanya bisa dilakukan apabila perkuliahan dialihkan secara daring maka bisa mencarinya sinyal yang bisa terfasilitasi dengan jaringan internet.

Adapun masalah yang kedua yang sering dihadapi mahasiswa prodi MPI IAIN Madura yaitu keterbatasan paket data internet sehingga terkendala dalam mengikuti perkuliahan yang dilaksanakan secara daring dan berdampak pada ketidak disiplinan mahasiswa dalam mengikuti perkuliahan yang dilaksanakan secara daring, maka solusi yang harus diberikan yaitu dengan membeli paket data atau bahkan bisa menggunakan wi-fi.

Adapun masalah yang selanjutnya kemungkinan jarang dihadapi oleh mahasiswa IAIN Madura yaitu dengan ketidak tersediaan alat bantu dalam proses perkuliahan yang dilaksanakan secara daring yang berupa teknologi seperti $\mathrm{Hp}$, Laptop, dan alat teknologi lainnya yang berupa teknologi karena dengan adanya fasilitas ini maka bisa melaksanakan perkuliahan yang dilaksanakan secara daring tapi masalah ini jarang dihadapi oleh mahasiswa prodi MPI karena melihat situasai saat ini dizaman yang penuh dengan teknologi tidak menutup kemungkinan semua mahasiswa akan tersedia alat-alat teknologi. Solusi yang seharusnya diberikan yaitu bisa membeli karena sudah tersedia banyak di toko-toko elektronik, selain itu bisa mencari pinjaman sehingga tetap bisa mengikuti perkuliahan yang dilaksanakan secara daring.

\section{KESIMPULAN}

Manajemen pembelajaran daring selama pandemik covid-19 manajemen pembelajaran yang digunakan diprodi MPI Fakultas Tarbiyah IAIN Madura yaitu; pertama dosen menjelaskan kontrak perkuliahan dengan meliputi berbagai macam aktivitas perkuliahan, kedua menyampaikan materi pelajaran dengan metode sistem diskusi kemudian materi yang diberikan dapat berupa file, Ppt, dan ditayangkan menggunakan video dan diperjelas dengan voicnote, ketiga memberikan tugas terhadap mahasiswa sebagai bahan evaluasi pembelajaran yang disampaikan, Dan yang keempat yaitu mengumpulkan tugas dengan menggunakan deadline di Google Clasroom.

Alat pendukungnya yitu; Pertama yaitu ketersediaan alat-alat teknologi seperti halnya Ponsel, Laptop, Komputer yang bisa memuat aplikasi-aplikasi khusus sebagai bentuk media penyampaian materi pembelajaran antara dosen dan mahasiswa, kedua ketergantungan dengan jarigan internet dan paket data yang dimiliki oleh mahasiswa.

Faktor penghambat yang sering dialami oleh mahasiswa prodi MPI Fakultas Tarbiyah IAIN Madura yaitu memiliki beberapa faktor penghambat sebagai mana menurut hasil penelitian dilapangan. Pertama tidak memiliki alat-alat teknologi seperti halnya Hp, Laptop, Komputer dan lain-lain, kedua keterbatasan koneksi internet yang dimiliki baik berupa jaringan dan kuota internet yang dimiliki. Adapun solusinya yaitu berusaha semaksimal mungkin dengan meminjam alat-alat teknologi sebagai media dalam pembelajaran, dan menggunakan layanan Wifi.

Penelitian dapat disarankan kepada semua dosen IAIN Madura bagaimana artikel dari penelitian ini dapat dijadikan refrensi atau tambahan pengetahauan serta dapat dijadikan refrensi atau acuan apabila ingin meniru strategi dosen prodi MPI dalam mendisiplinkan mahasiswanya ketika proses perkuliahan dilaksanakan dengan jarak jauh apalagi pada saat situasi pandemik covid-19 saat ini. Untuk mahasiswa saran dasar penelitian ini setiap hambatan yang terjadi jangan dijadikan rintangan melainkan 
dijadikan tantangan supaya tetap disiplin dalam mengikuti aktivitas perkuliahan yang dilaksanakan secara daring untuk mencapai hasil pembelajaran yang maksimal.

\section{DFTAR PUSTAKA}

Adisuwingnjo, Supriatna. Panduan Pembelajaran Daring Dalam Rangka Menghadapi Pandemik Covid-19. Malang: Politeknik Negeri. 2020.

Afrizal. Metode Penelitian Kualitatif Sebuah Upaya Mendukung Penggunaan Oenelitian Kualitatif Dalam Berbagai Disiplin Ilmu. Jakarta: Raja Wali Pers. 2015

Agustino, Eko Dano. Memahami Metode Penelitian Kualitatif. Yogyakarta: Calpulis. 2015

Andrian. "Upaya Pembinaan Fisik dan Mental (Pem) Dalam Membangun Kedisiplinan Siswa di SMK PGRI 3 Cimahi”. Jurnal Untirta Civic Education. Vol 2. No 1. Desember 2017. ISSN. 2541-6693

Arikunto, Suharsimi. Prosedur Penelitian. Jakarta. Rineka Cipta. cet 15. 2013.

Astuti, Puji. Blended Learning Syarah Bagaimana Penerapan dan Persepsi Mahasiswa, Jurnal Gantang. vol iv. No 2. eISSN 2548-5547. p ISN 2503-0011.

Bilfaqih, Yusuf. Esensi Pengembangan Pembelajaran Daring. Yogyakarta: Deepublish, 2015

Bungin, Burhan. Penelitian Kualitatif. Jakarta: Renada Media Group. Cet ke 6. 2012.

Djumingin, Nengsih Sulastri. Strategi dan Aplikasi Model Pembelajaran Inovatif Bahasa dan Sastra. Makassar: Badan Penerbit UNM Makassar. 2016.

Efendi, Yosep. Penguatan Karakter Mandiri Disiplin Kerja Sama Kreatif ("Mari Kerja Kreatif) Melalui Lesson Study Pada Pembelajaran Teknologi Sepeda Motor. Jurnal Pendidikan Vokasi Otomotif. Volume 1. Nomor 1. November 2018.

Erwinsyah, Alfian. Manajemen Pembelajaran Dalam Kaitannya peningkatan Kualitas Guru, Jurnal Manajemen Pendidikan Islam, Volume 5. Nomor. 1 Februari 2017

Gulo. Metodologi Penelitia., Jakarta: Gramedia Widia Sarana. 2002.

Hadayani, Lina. Keuntungan, Kendala dan Solusi Pembelajaran Online Selama Pandemik Covid-19 Studi Eksploratif SMPN 3 Kudus, Jurnal Jemar. Volume 1. Nomor 2. Juli 2020.

Huberman, Amchael Miles B Matthe. Qualitatife data analysis. America: Sage Publications. 2014.

Junaidi, Aris Nizam. Panduan Pembelajaran Daring Bagi Mahasiswa Dengan Disabilitasi Netra 2020. Jakarta: Direktorat Jendral Pendidikan Tinggi. 2020.

Khasanah, Uswatun dan Ayu Ratu Dian. Pendidikan Dalam Masa Pandmei Covid-19. Jurnal Sinestesia. Vol 10. No 1. April 2020.

Kusnayat, Agus. Pengaruh Teknolgi Pembelajaran Kuliah Oline Diera Covid-19 dan Dampaknya Terhadap Mental Mahasiswa, Jurnal Edukasi Dan Teknologi Pembelajaran. Volume 1. No 2. Juni 2020.

Moleong, J. Lexy. Metodologi Penelitian Kualitatif. Bandung: Remaja Rosdakarya. cet 35. 2016.

Mulyasa. Manajemen Pendidikan Karakter. Jakarta. Bumi Aksara. Cetakan ke 6. Agustus 2018. 
Mustofa, Dikkil Muhammad, dkk. "Formulasi Model Perkuliahan Darimg Sebagai Upaya Menekan Disparitas Kualitas Perguruan Tinggi”. Jurnal of Information Tecnology. Vol 1. No 2. 2019. Isn151-160.

Novita, Lina. Hubungan Antara Konsep Diri Dengan Sisplin Siswa. Jurnal Pendidikan Dan Pengajaran Guru Sekolah Dasar. Volume 02. Nomor 01. Maret 2019.

Omery, Nopan. Pentingnya Pendidikan Karakter Dalam Dunia Pendidikan. Jurnal Manajer Pendidikan. Volume 9. No 3. Juli 2015.

Pangondian, Andriyanto Roman. Faktor-Faktor yang Memepengaruhi Kesusksesan Pembelajaran Daring dalam Revolusi Industri 4.0. Seminar Nasional Teknologi Komputer \& Sains (SAINTEKS). ISBN 978-602-52720-1-1.

Pebriyanti, Diah Putu. Keunggulan Dan Kelemahan Menggunakan Metode Pembelajaran Elearning. Ganisha University of Education. April 2020.

Pratiwi, Windiyani Ericha. Dampak Covid-19 Terhadap Kegiatan Pembalajaran Online di Sebuah Perguruan Tinggi Kristen di Indonisia. Artikel Perspektif Ilmu Pendidkan. Volume 34,. Issue 1. April 2020.

Purhantara, Wahyu. M. Metode Penelitian Kualitatif untuk Bisnis. Yogyakarta: Graha Ilmu. 2010.

Purnomo, Halim. Pendidikan Karakter Islami Pada Onnline Class Managamenet Di Sma 7 Muhamamdiayh Yogyakarta Selama Pandemik Covid-19. Jurnal Tarbiyatuna, Vol 11. No 1. 2020.

Purwanto, Agus, dkk. "Studi Eksploratif Dampak Pandemi Covid 19 Terhadap Proses Pemeblajaran Online di Sekolah Dasar", Jurnal Of Education Psycology and Conseling, Volume 2. Nomor 1. 2020. Issn Online: 2716-4446.

Racoo. Metode Penelitian Kualitatif Jenis, Karakteristik, dan Keunggulannya. Jakarta: PT. Gramedia Widiasarana. 2010.

Rahman, Faitkhur. Peran Pendiidik dalam Pembinaan Disiplin Siswa di Sekolah/Madrasah. Artikel Arobiyah. 04 Januari 2018.

Rahmat, Nur. Pembentukan Karakter Disiplin Siswa Melalui Guru Kelas di SD Negeri 3 Rejosari Kabupaten Oku Timur. Jurnal Manajemen Kepemimpinan dan Supervisi Pendidikan, Volume 2. No. 2 Desember 2017.

Rofiatun, and Mohammad Thoha. "MANAJEMEN PEMBINAAN KEDISIPLINAN SANTRI DALAM MENGIKUTI KEGIATAN KEAGAMAAN DI PONDOK PESANTREN NURUS SHIBYAN AMBAT TLANAKAN PAMEKASAN." $r e-$ JIEM (Research Journal of Islamic Education Management) 2, no. 2 (2019): 278-287.

Roikan, Aminah. Pengantar Metode Penelitian Kualitatif Ilmu Politik. Jakarta: Kencana. cet 1. Januari 2019.

Safira, Holmi Nabil, dkk. Persepsi Mahasiswa Terhadap Perkuliahan Daring Sebagai Sarana Pembelajaran Selama Masa Karantina Covid 19. Jurnal Bisnis dan Kajian Strategi Manajemen. Volume 4. No. 1. 2020. ISSN : 2614-2147.

Setiawan, Rifqi Adib. Lembar Kegiatan Literasi Saintifik Untuk Pembelajaran Jarak Jauh Topik Penyakit Corona Virus 2019 (coovid 19). Jurnal Edukatif. Vol. 2. Nomor 1. April 2020

Siswanto, Aris Victorianus. Strategi dan Langkah-Langkah Penelitian. Yogyakarta: Graha Ilmu. 2012

Sugiyono. Metode Penelitian Kualitatif. Bandung: Alfabeta. 2017. 
Suradi. Pembentukan Karakter Siswa Melalui Penerapan Disiplin Tata Tertib Sekolah. Jurnal Riset dan Konseptual. Volume 2. Nomor 4. November 2017

Surjono, Dwi Herman. Membangun Course Elerning Berbasis Moodle. Yogyakarta. UNY Press. 2010.

Syamsuddin, dkk. Metode Penelitian Pendidikan Bahasa. Bandung: Remaja Rosdakarya. cet 4. 2011.

Warsidi, Editor Eicmann Chaerul. Membangun Disiplin dalam Mendidik. CV Putra Setia, 2011.

Wedi, Restu Kartiko. Asas Metodologi Penelitian. Yogyakarta: Graha Ilmu. 2010.

Wibowo, Agus. Manajemen Pendidikan Karakter di Sekolah. Yogyakarta: Pustaka Pelajar. Cet ke 2. Juni 2016

Widarto. Model Pembelajaran Cooperative Learning on Project Work. Yogyakarta: Pustaka Pelajar. 2017

Wijaya, Hengki. "Pengembangan Model Pembelajaran Pendidikan Karakter Berbasis Media Sosial". 17 Februari 2019

Yuda, Abi Seno. Persepsi Mahasiswa Terhadap Pelaksanaan Elearning dalam Mata Kuliah Manajemen Sistem Informasi Mahasiswa Jurusan Teknologi Pendidikan Uneversitas Negeri Malang, Jurnal Kajian Teknologi Pendidikan. Vol 2. No. 3. Agustus 2019.

Zamzam Fakhri Firdaus. Aplikasi Metodologi Penelitian. Yogyakarta: Grup Penerbit Utama. 2018. 